\title{
The Lepenski Vir conundrum: reinterpretation of the Mesolithic and Neolithic sequences in the Danube Gorges
}

\author{
DUŠAN BORIĆ*
}

\begin{abstract}
This paper employs new evidence - including new AMS dates - to support a reinterpretation of the stratigraphic and architectural phasing of Lepenski Vir, and links this new evidence with the Mesolithic-Neolithic transition in the region by critiquing dominant models.
\end{abstract}

Key-words: Lepenski Vir, Danube Gorges, Mesolithic, Neolithic, AMS dates

\begin{abstract}
Introduction
The Danube Gorges provide the richest archaeological dataset for the study of the MesolithicNeolithic transition in southeast Europe: the transformation of complex hunter-gatherers; the first houses and the development of sedentism; indigenous domestication of animals; mechanisms of culture change in foragerfarmer interactions; the development of social and symbolic complexity. Interpretation of the archaeological record at the type site of Lepenski Vir has fuelled intensive debate over dating and the context of Neolithic pottery (Borić 1999; Tringham 2000; Garašanin \& Radovanović 2001).
\end{abstract}

\section{Landscape setting}

The Lepenski Vir culture sites are in a geologically complex area of the Danube/Iron Gate gorges (FIGURE 1). The Danube cuts a 130- km route through the southern fringes of the Carpathians, passing the intermittently steep cliffs of four gorges (Atlas 1972; MarkovićMarjanović 1978) and cataracts, whirlpools and large 'cauldrons' formed by intensive erosion of the Danube riverbed. In pre-modern times, there was good fishing supplied by migratory sturgeon, catfish, carp and other species. Rockshelters and lower terraces of the Danube were the foci of human settlement. The paper addresses the Upper Gorge sites of Lepenski Vir, Padina and Vlasac, although other sites are both downstream and outside the gorges (FIGURE 1).
The landscape is critical for frontier models between the foraging populations in the gorges and the surrounding farming communities.

\section{Early Neolithic material culture, buildings and the dating of Lepenski Vir}

The key sites of Lepenski Vir and Padina share a number of similar features: trapezoidal dwelling floors with rectangular hearths made of vertical stone slabs placed in the centre of each dwelling. At Padina, the excavator Jovanović identified the architectural features of trapezoidal dug-in buildings as Early Neolithic (pottery, yellow-spotted/Balkan flint and ground polished stone axes) (Jovanović 1969; 1987; Borić 1999). By contrast, at Lepenski Vir, Srejović identified similar architectural features as Mesolithic, by a different interpretation of depositional processes and contexts (Srejović 1969; 1972; Garašanin \& Radovanović 2001: n 2). Several authors (Jovanović 1969; Gimbutas 1976; Milisauskas 1978; Tringham 2000) have suggested that the Early Neolithic pottery associated with trapezoidal buildings at Lepenski Vir is not solely intrusive, but stratigraphically and contextually associated with these architectural units. I examined the existing evidence from Lepenski Vir in relation to the neighbouring site of Padina (Borić 1999: 47-55). At Padina, abundant Early Neolithic pottery is clearly associated with trapezoidal buildings in a number of published photographs (FIGURE 2; Jovanović

\footnotetext{
* Department of Archaeology, University of Cambridge, Downing Street, Cambridge CB2 3DZ, England. db231@hermes.cam.ac.uk
}

Received 3 October 2000, accepted March 2001, revised 3 August 2001, August 2002 


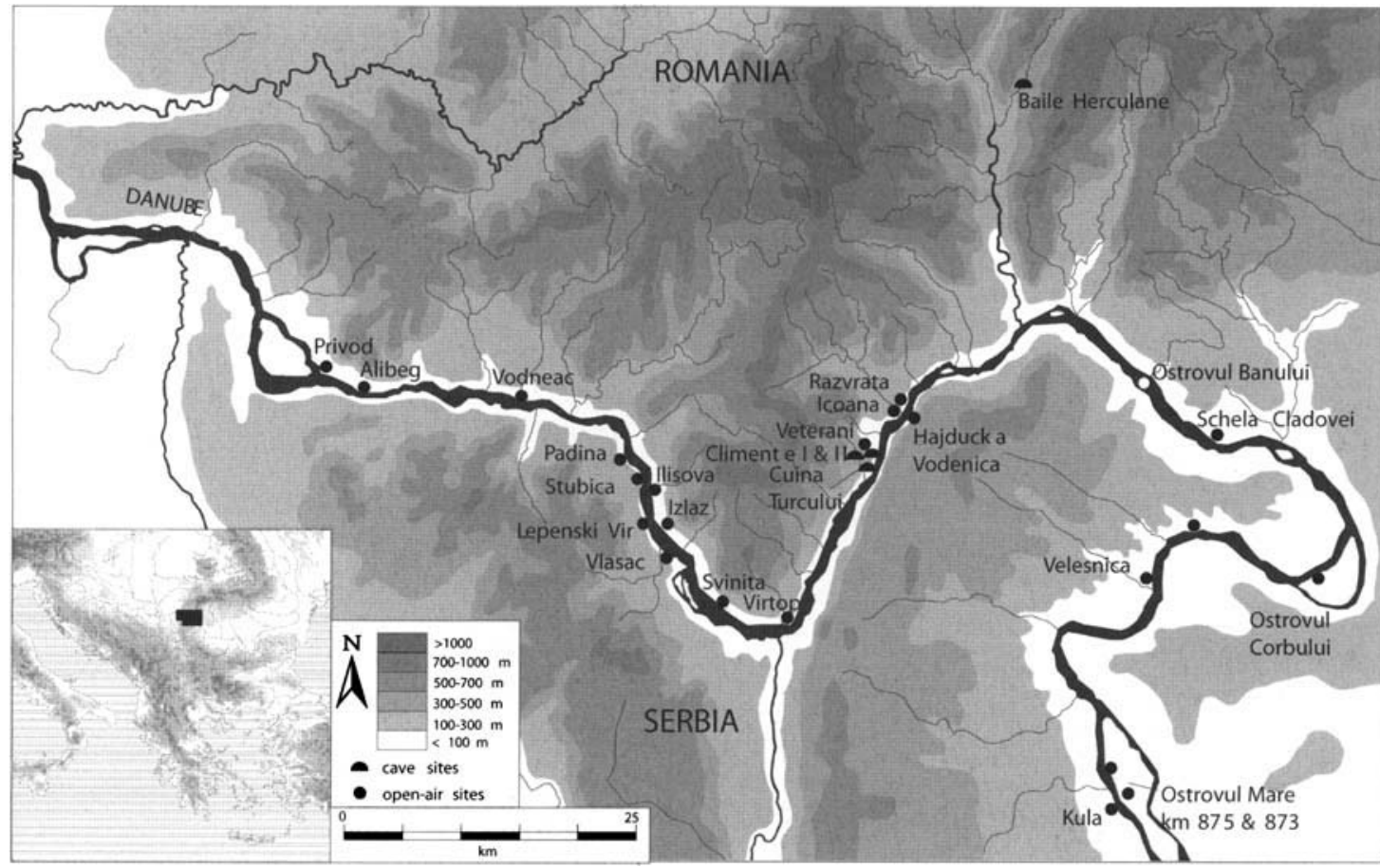

FIGURE 1. Map showing principal sites with the Early Holocene sequences in the Danube Gorges.

FIGURE 2. House 18 from Padina with in situ pottery. (Photo courtesy B. Jovanović).

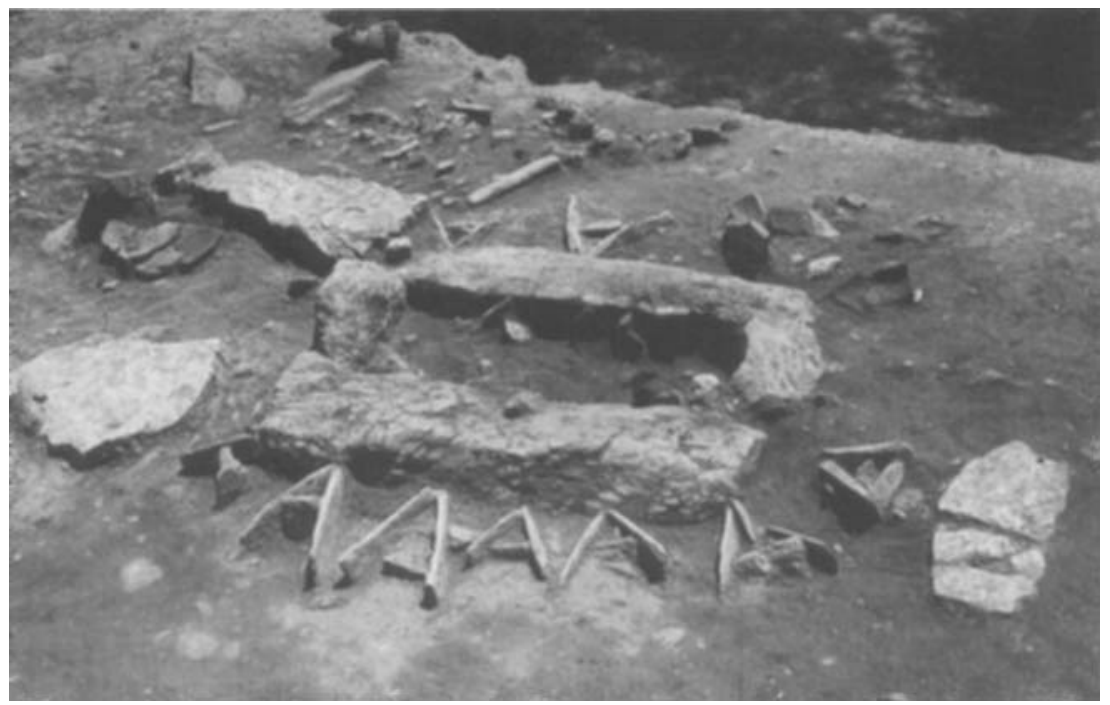

1969; 1987). At Lepenski Vir, Srejović reports that the Early Neolithic pottery found in situ on building floors or between the overlapping floors is intrusive (1968: 86; 1969: 153-4; 1971: 5; 1972: 134).

I argue that reinterpretation of Lepenski Vir's phasing, and hence deposition of material cul- ture, can only be achieved by reference to topography and construction. Both at Padina (at Sector III) and at Lepenski Vir the dwellings were dug in sandy loess terraced slopes, facing the Danube. On most of the photos, these dwellings seem decontextualized by appearing as pedestalled features (FIgURE 3). At Padina, 


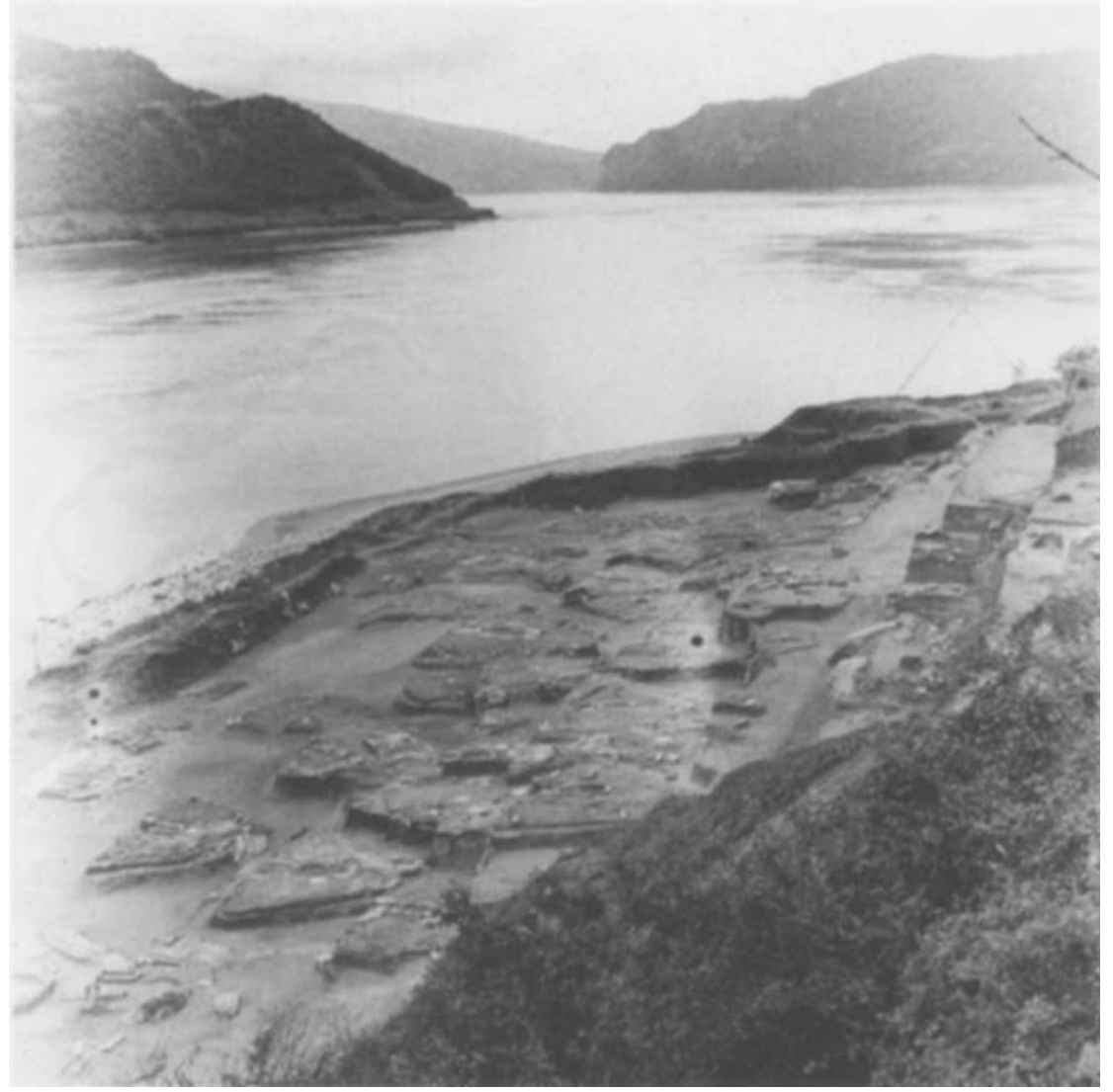

FIGURE 3. Excavated houses at Lepenski Vir and the surroundings. (Photo Srejović \& Babović 1983: 32). sections show the stratification of deposits above floors (Jovanović 1969; Borić 1999), indicating that these buildings were dug 1-1.5 $\mathrm{m}$ into the sloping terrace. Similarly section drawings and photos from Lepenski Vir (Srejović 1967b: profile 1; 1972: Radovanović 1996a: figures 3.27, 3.17) - such as the section above the floor of House 27 (FIGURE 4) - show the cultural debris infill of a semi-subterranean dwelling. Hence Early Neolithic material culture excavated at Lepenski Vir was deposited in the infill of many trapezoidal buildings during what the excavator considers the 'Mesolithic' phases Ia-e and II (Borić 1999: 52). More recently Radovanović (2000a; Garašanin \& Radovanović 2001) published two previously unpublished photographs of complete Early Neolithic pots in situ on the floor of House 4 and in the hearth of House 54 at Lepenski Vir. This evidence further supports my previous findings. ${ }^{1}$

1 For reasons of archaeological politics, these photos were withheld from publication until 2001.
In order to explain the presence of the Early Neolithic pottery, most commentators rely on the frontier model of forager-farmer interaction and view the Early Neolithic material culture as an import into the Danube Gorges (Voytek \& Tringham 1989; Chapman 1992; Radovanović 1996b). It is difficult to imagine that large amounts of Early Neolithic pottery associated with trapezoidal buildings at Padina were imported from the area outside the Danube Gorges. It seems more reasonable to assume that these large amounts of pottery were manufactured locally at both Lepenski Vir and Padina.

Further detailed stratigraphic publication of the Early Neolithic material culture from Lepenski Vir is required to establish whether all buildings of Lepenski Vir I are of the Early Neolithic age, or to separate a few that precede the appearance of the Early Neolithic material culture. In the meantime, radiometric dating provides a complementary way to achieve a finer resolution of the chronological scale for these sites. 
FIGURE 4. House 27, section through the rear area of the structure; Lepenski Vir. (Photo

Radovanović 1996a: figure 3.27). White dotted line underlines and follows the soil difference of the sterile deposit (left) and the dwelling infill (right), showing the level from which the pit for the dwelling was cut into the slope.

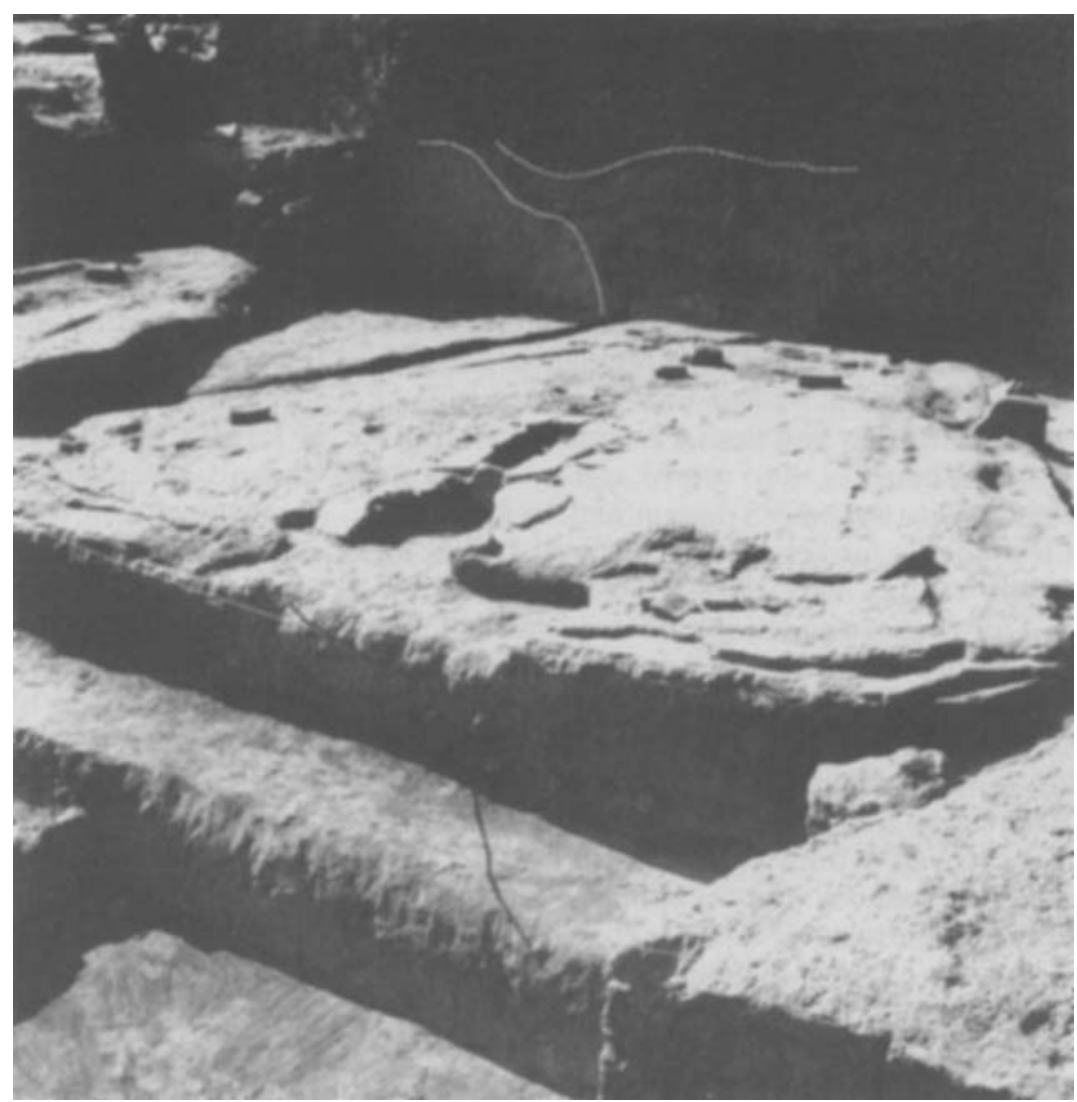

Lepenski Vir: charcoal conventional dates

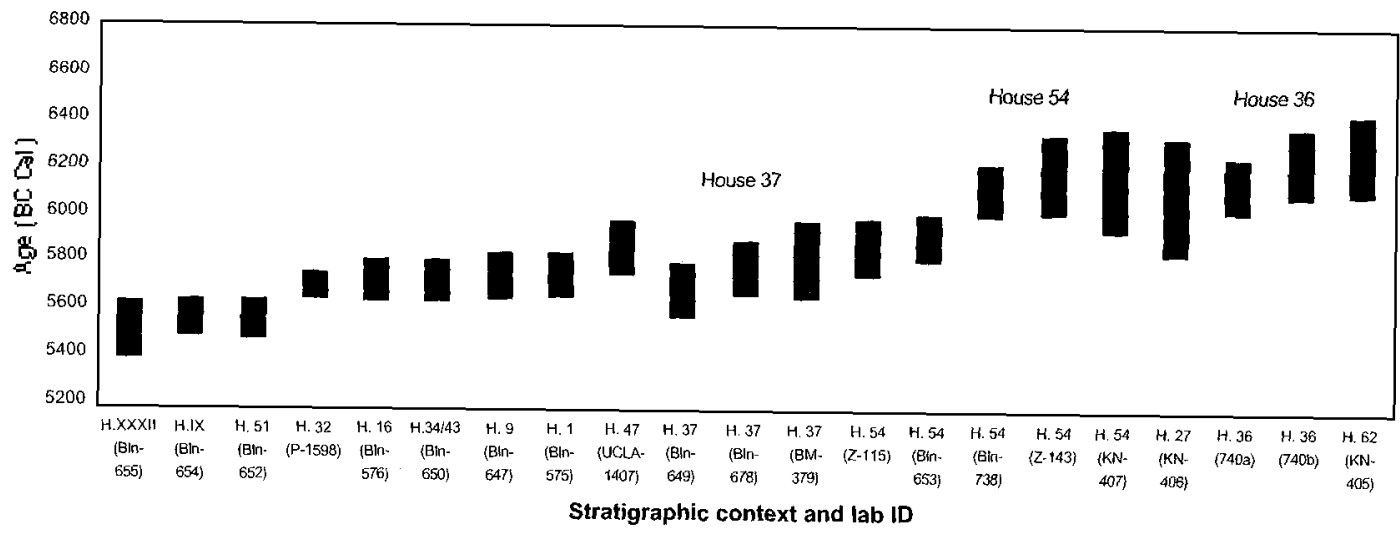

FIGURE 5. Calibrated conventional radiocarbon dates on charcoal from building floors and hearths at Lepenski Vir (after Quitta 1975; OxCal v. 3.4). Solid bars show 1 s.d.; lines show 2 s.d. Framed dates come from the same buildings. 


\section{Absolute chronology and palaeodietary patterns}

At Lepenski Vir, conventional ${ }^{14} \mathrm{C}$ charcoal dates from building floors and hearths (Quitta 1975: 283; FIGURE 5) are evenly distributed between $c$. 6200 and $5400 \mathrm{cal} \mathrm{BC.}{ }^{2}$ The dates confirm that the settlement (Srejović's phases LV Ia-e and II) is contemporary with Early Neolithic sites in the Morava, middle Danube and Tisza valleys of the north-central Balkans. Conventional radiometric determinations at Padina from the same type of context (hearths and timber beams of the upper building construction) are in agreement (Borić 1999: figures 6-7). AMS determinations from both sites provide further evidence (TABLE 1; FIGURES 6a, 6b; Whittle et al. 2001).

The first unquestionable evidence of the Mesolithic occupation at Lepenski Vir is based on one new AMS date on a herbivore bone (OxA8610: 8770 $600 \mathrm{BP}$, TABLE 1). The dating indicates much earlier deposits at Lepenski Vir - 8200$7600 \mathrm{cal} \mathrm{BC}(2 \sigma)$ (FIGURE 6a). The dated sample was recovered from an area of intensive black soil and charcoal with an animal bone concentration underneath House 23. This demonstrates the phase of Proto-Lepenski Vir identified by Srejović $(1969 ; 1972: 45-9)$ representative of a number of open-air rectangular hearths, thin occupation deposits sealed by later limestone floors and a number of human burials (e.g. probably Burial 69 in the sitting position, extended inhumations Burials 13-17, etc.; see FIGURE 7).

Thus one can suggest two distinct phases at Lepenski Vir: Proto-Lepenski Vir of clearly Mesolithic age and Lepenski Vir I (with features such as trapezoidal buildings) of Early Neolithic date. Although Mesolithic features (open-air hearths and burials) might be connected with the later development of this settlement, new AMS dates are necessary to clarify the details of the sequence.

Five new AMS dates for human burials of Early Neolithic date at Lepenski Vir are not associated with the trapezoidal structures (see FIGURE 7). Dating of human burials in the Danube Gorges is affected by the freshwater reservoir effect from the substantial dietary intake of freshwater fish, thus requiring a correction of 200-500 years

2 As the dates were done mainly on oak charcoal (Quitta 1975: 283), and bearing in mind problems associated with 'old wood', they should be considered as only the oldest possible dates for the use of the dated buildings ( $c f$. Bonsall et al 2000: 128), i.e. their perishable upper construction.
(Bonsall et al. 2000; Cook et al. 2002). The same applies to one dated fish bone from Lepenski Vir (OxA-8725) and three dated dog bones from Padina with a similarly high $\delta^{15} \mathrm{~N}$ (TABLE 1) indicating a diet rich in fish consumption. ${ }^{3}$

Bonsall et al. (1997; 2000) use stable isotope data from the Danube Gorges as a proxy dating tool and suggest that a dietary shift from aquatic to more terrestrial food sources coincides with the appearance of Early Neolithic material culture and the development of agriculture. This is largely based on five dates from Lepenski Vir and assumes a rather swift change of the diet underlining the Mesolithic-Neolithic subsistence dichotomy. However, the zooarchaeological data from the sites in question (Dimitrijević in press; Dimitrijević \& Borić forthcoming) do not support this model. On the basis of (re)analyses of faunal assemblages from Padina and Lepenski Vir, the remains of sturgeon (primarily migratory beluga fish) were clearly present on the floors of trapezoidal buildings (contra Bonsall et al. 2000: 121) probably of Early Neolithic date. Furthermore a number of mammal bones were found in what are clearly Mesolithic contexts of the two sites, suggesting a rather mixed diet during the Mesolithic as well. Moreover, there is no evidence at Padina and Lepenski Vir for the supposed development of agriculture and farming at the beginning of the Neolithic. Some authors (e.g. Voytek \& Tringham 1989; Tringham 2000; Zvelebil \& Lillie 2000) have suggested that a small number of domestic animals, at Lepenski Vir and Padina, indicate supposed contact and exchange between foragers and the first farmers in the surrounding regions. Recent faunal (re)analyses do not suggest any such clear association of domestic animals and architectural features.

Without rejecting the validity of isotopic data on palaeodietary patterns for the region, one must address the full complexity of sometimes conflicting strands of evidence before developing models of culture change. In other words, it is necessary to develop a more flexible model for the Mesolithic-Neolithic transition in the Dan-

3 Bonsall et al. (2000: 123; see Cook et al. 2002) calculate the magnitude of the corrected factor as $540 \pm 70$ radiocarbon years in relation to $\delta^{15} \mathrm{~N}$ value and apply this to the dated human bones from the Danube Gorges (Bonsall et al. 2000: table 3). It is possible to estimate a similar correction factor for the dated fish bone from Lepenski Vir and dog bones from Padina (cf. Whittle et al. 2001). 
Padina: AMS dates on animal bones

Lepenski Vir: AMS dates on animal bones

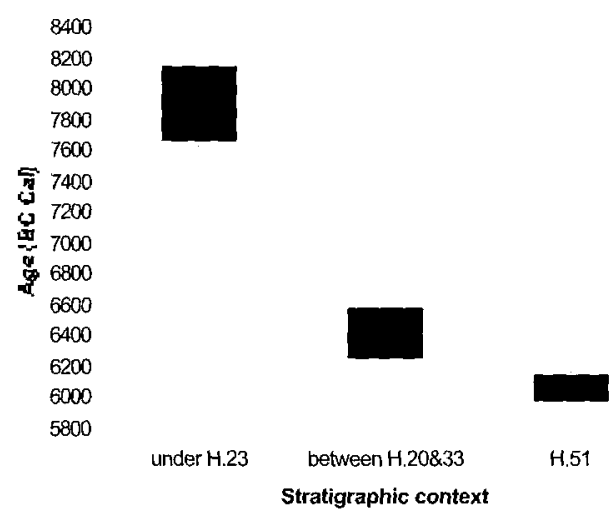

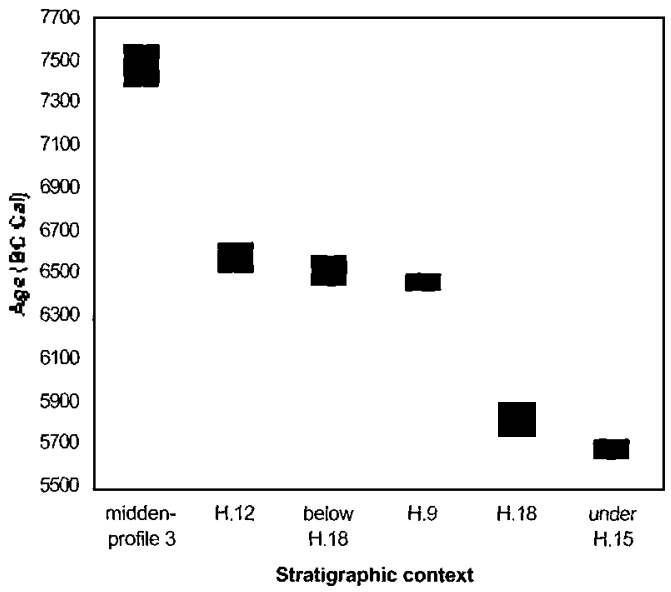

FIGURE 6. Calibrated AMS dates on animal bones from deposits on and beneath building floors at Lepenski Vir and Padina (see TABLE 1). Framed dates need to be corrected for the freshwater reservoir effect and are 200-500 years younger (see note 3).

\begin{tabular}{|c|c|c|c|c|c|c|}
\hline context & material & lab. no. & $\delta^{13} \mathbf{N}$ & $\delta^{13} \mathrm{C}$ & ${ }^{14} \mathrm{C}$ age $\mathrm{BP}$ & $\begin{array}{r}\text { calibrated } \\
(2 \sigma)\end{array}$ \\
\hline $\begin{array}{l}\text { Lepenski Vir } \\
\text { under House } 23\end{array}$ & $\begin{array}{l}\text { large mammal } \\
\text { long bone }\end{array}$ & OxA-8610 & $4 \cdot 7$ & $-21 \cdot 6$ & $8770 \pm 60$ & $8200-7600$ \\
\hline $\begin{array}{l}\text { between floors of Houses } \\
20 \text { and } 33\end{array}$ & fish bone & OxA-8725 & $9 \cdot 7$ & $-16 \cdot 9^{*}$ & $7600 \pm 90$ & $6600-6230^{*}$ \\
\hline $\begin{array}{l}\text { under the level of House } \\
\text { XLIV - the rear of } \\
\text { House } 51\end{array}$ & $\begin{array}{l}\text { large mammal } \\
\text { long bone }\end{array}$ & OxA-8618 & $3 \cdot 9$ & $-21 \cdot 2$ & $7200 \pm 60$ & $6220-5980$ \\
\hline $\begin{array}{l}\text { Padina } \\
\text { midden, Profile } 3 \text { segment } 1 \text {, } \\
\text { excavation level } 3\end{array}$ & red deer mandible & OxA-9055 & $4 \cdot 7$ & $-20 \cdot 8$ & $8445 \pm 60$ & $7600-7340$ \\
\hline $\begin{array}{l}\text { above House } 12 \text { - under } \\
\text { the level with animal } \\
\text { bones }\end{array}$ & dog tibia & OxA-9034 & $8 \cdot 6$ & $-17 \cdot 7^{*}$ & $7755 \pm 65$ & $6700-6440^{*}$ \\
\hline below the floor of House 18 & dog ulna & OxA-9053 & $11 \cdot 3$ & $-17 \cdot 7^{*}$ & $7685 \pm 60$ & $6640-6430^{*}$ \\
\hline House 9 & dog tibia & OxA-9056 & $12 \cdot 5$ & $-18 \cdot 1^{*}$ & $7625 \pm 55$ & $6600-6380^{*}$ \\
\hline floor of House 18 & red deer antler & OxA-9052 & $6 \cdot 6$ & $-22 \cdot 2$ & $6965 \pm 60$ & $5930-5720$ \\
\hline under floor of House 15 & $\begin{array}{l}\text { worked mammal } \\
\text { bone }\end{array}$ & OxA-9054 & 5.7 & -21.5 & $6790 \pm 55$ & $5780-5610$ \\
\hline
\end{tabular}

* dates need correction for freshwater reservoir effect (c. 200-500 years younger).

TABLE 1. AMS dates from Lepenski Vir and Padina (after Whittle et al. 2001; OxCal v. 3.4).

ube Gorges that incorporates new evidence and re-examines stratigraphic relations. Before discussing a revised transition, I shall provide an ideal reconstruction of a Lepenski Vir I building, which is an important first step for the re-phasing of the site's stratigraphy and architecture.

\section{Lepenski Vir phasing and building reconstruction}

Trapezoidal buildings at Lepenski Vir I were dug into the terrace slope (Srejovic 1969: 62; 1972: 62), and provided with limestone floors. The earliest examples in the Danube Gorges 


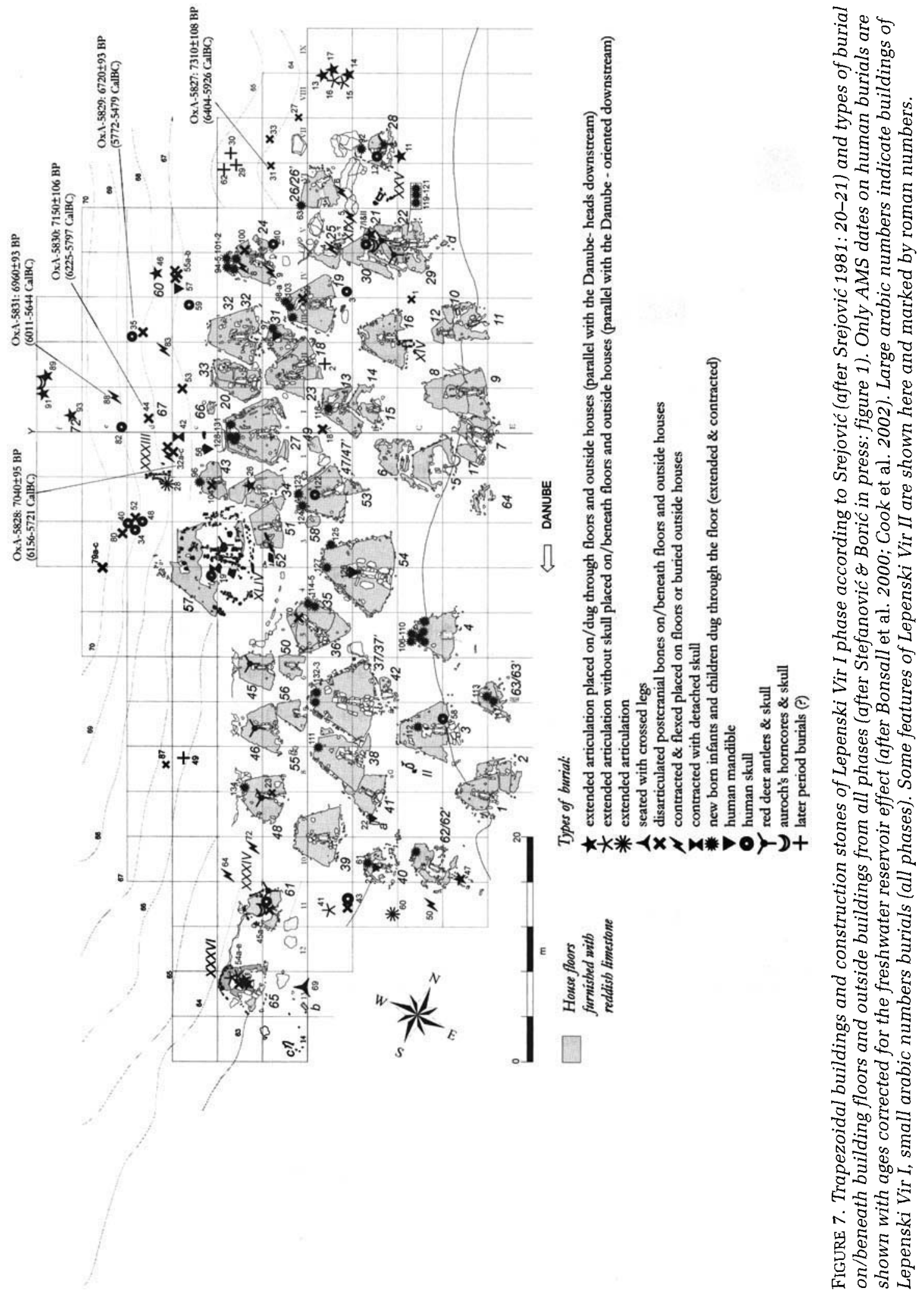




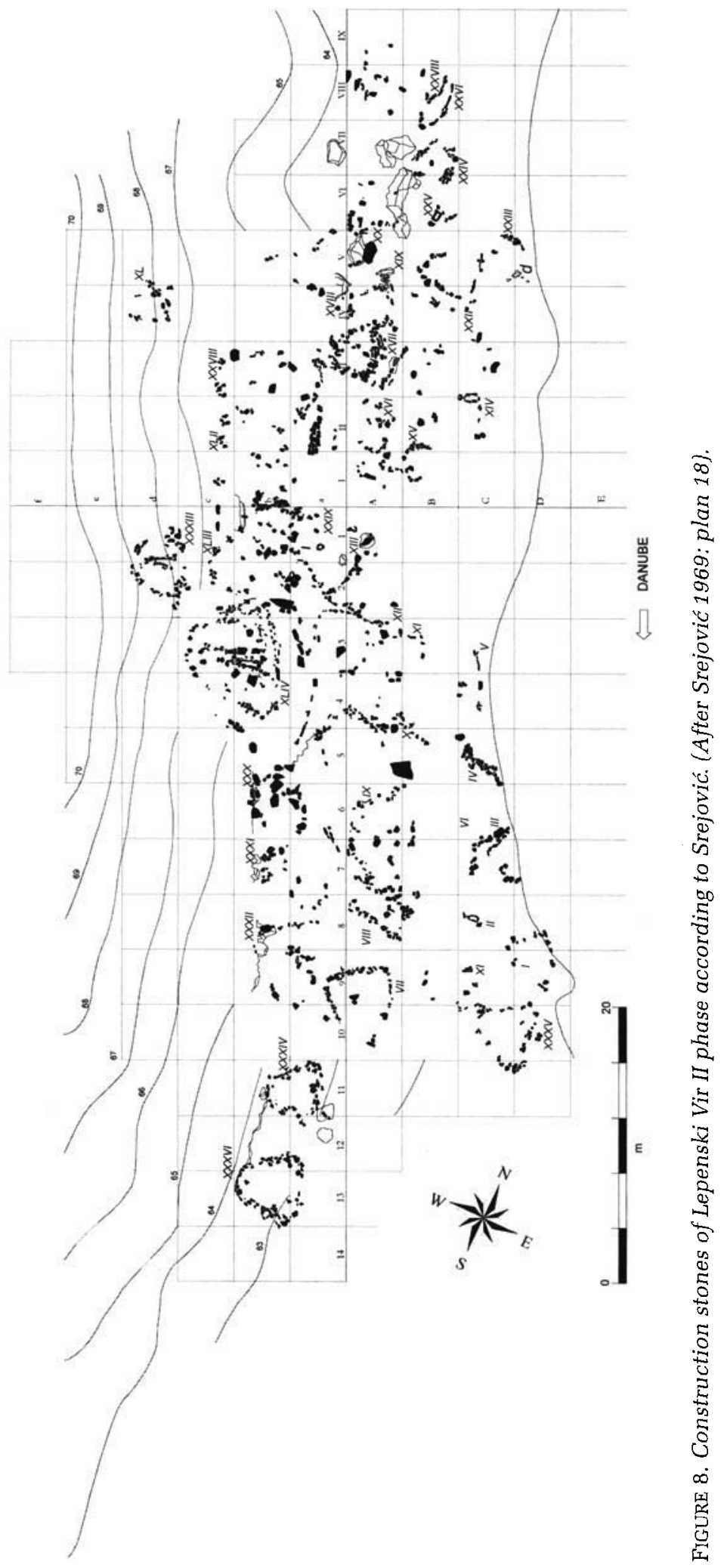




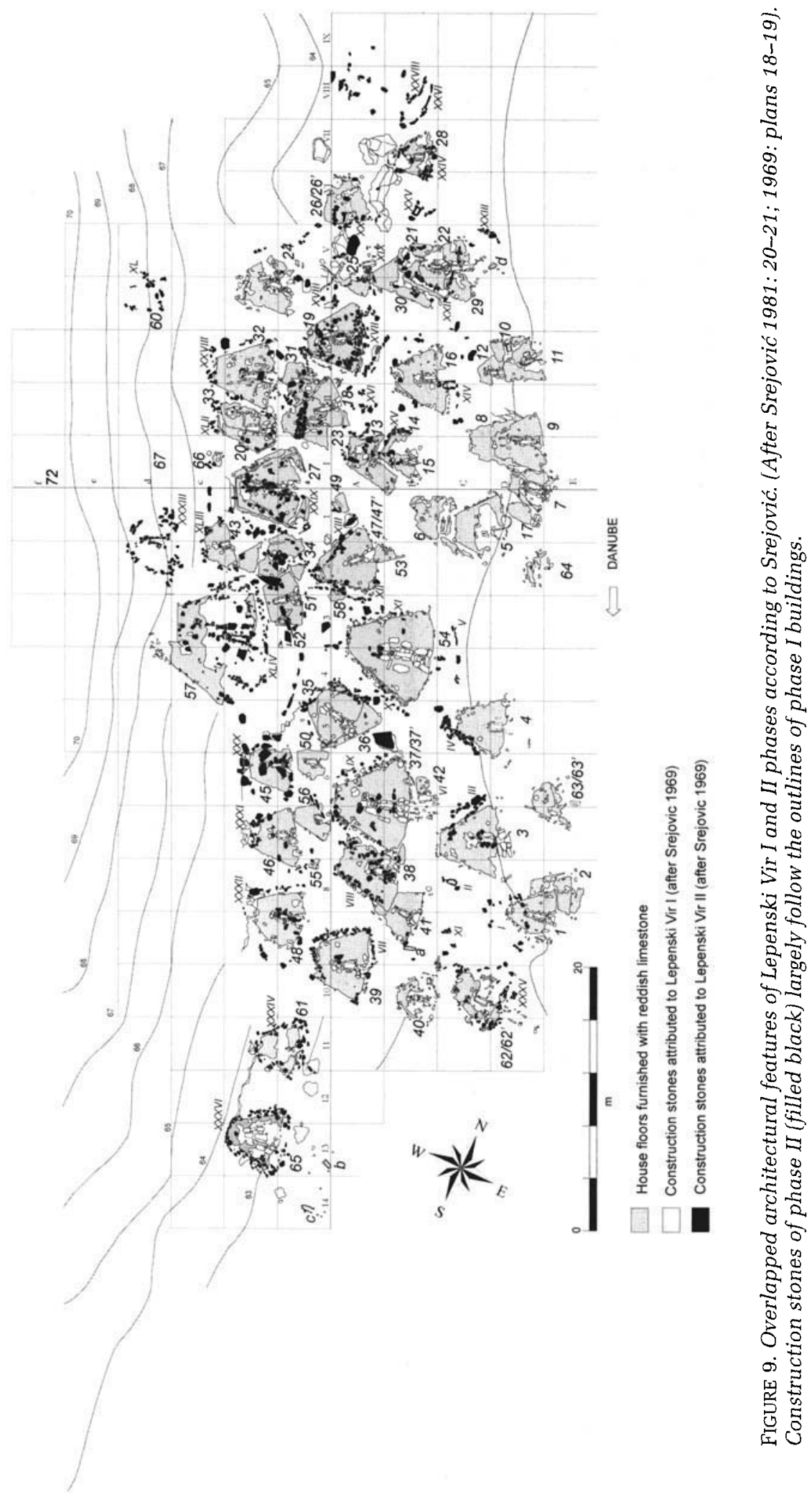


Figure 10. A new reconstruction of a building at Lepenski Vir. (John Gordon Swogger, Bryce v. 5.0.)

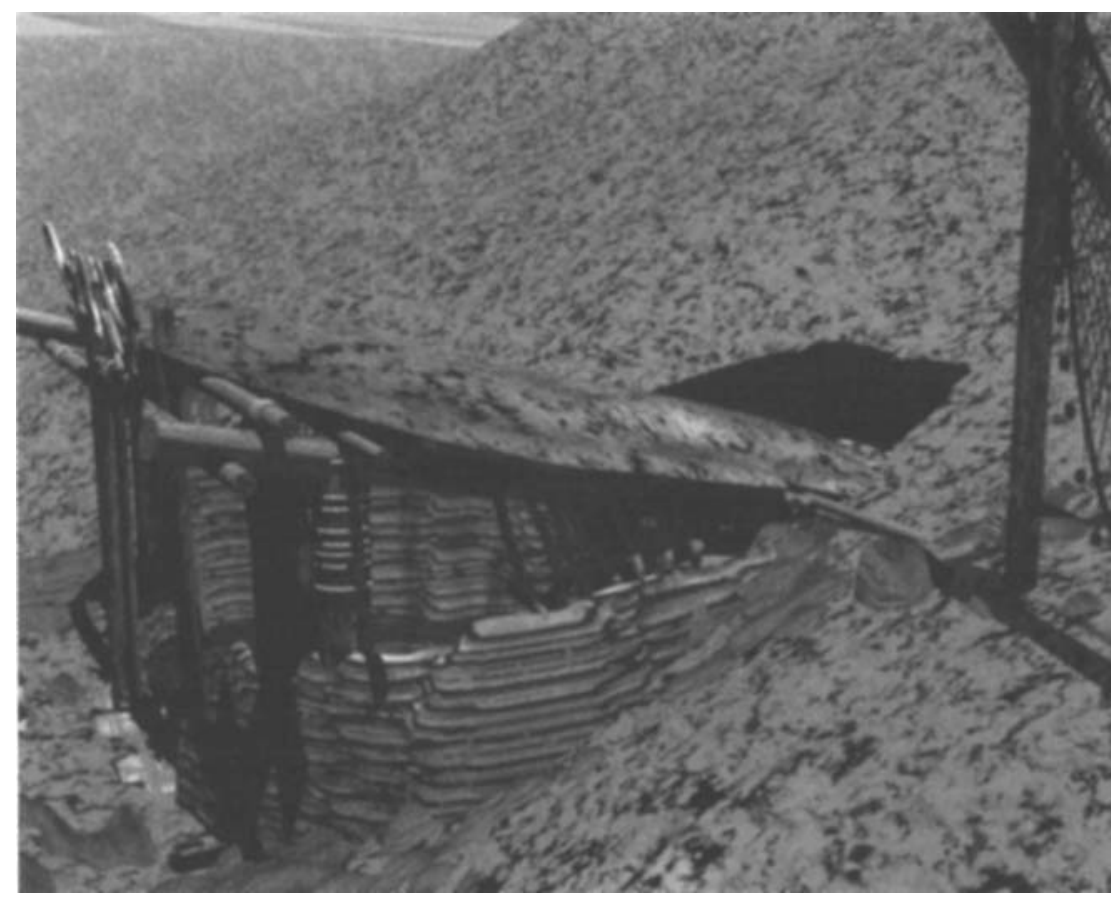

come from neighbouring Vlasac (Srejović \& Letica 1978). The trapezoidal shape of the building floor is an explicit reference to the trapezoidal Treskavac Mountain situated across the Danube in front of Lepenski Vir (also visible from Vlasac and Padina in the Upper Gorge), an impressive landmark mirrored the layout of domestic space (Borić in press). The floor was only plastered with reddish limestone at Lepenski Vir. Existing photos from Lepenski Vir misleadingly show these semi-subterranean dwellings and their floors placed on a flat terrace, whereas they were actually dug down some 0.5-1.5 m (see FIGURE 4) and this has not previously been recognized. It is also necessary to take into account the rows of stone that bordered the sides and rear of the building floor, casting doubt on the identification of layer/phase Lepenski Vir II. This phase was described by the excavator as consisting of rows of stone in a trapezoidal shape without central hearths (FIGURE 8) and overlaying trapezoidal buildings of phase I. By superimposing ${ }^{4}$ trapezoidal buildings of LV I (FIGURE 7) with stone walls of Phase LV II (FIGURE 8) it becomes obvious that con-

4 The excavation grid recently published by $\mathrm{L}$. Radovanović (2000: figure 2) is wrongly offset one quadrate along y axis. This correction is based on an unpublished plan from Lepenski Vir, courtesy of M. Jevtić (University of Belgrade). struction stones of Phase LV II encircle limestone floors of Phase LV I (FIGURE 9) and are especially pronounced in the steeper terrain of the rear part of the settlement.

This evidence suggests that architectural features previously identified as Lepenski Vir II are stone footings and walls that surrounded the dug-in sides of the Lepenski Vir I post-framed buildings. Furthermore, the roofs of buildings at the site were flat and followed the trapezoidal outline of the floor (FIGURE 10). This differs from the previous reconstruction of a ridged, tentlike construction of the roof. The updated reconstruction is based on the preserved constructional elements of buildings and data on the position of collapsed charred remains of timber beams found on building floors. On the site plan of Lepenski Vir (FIGURE 7), postholes were visibly cut into the edge of the floor of large buildings, such as 54 and 37 , and reinforced with stone footings in a shallow bedding trench. They are placed on the wide front part and two-thirds back from the front towards the rear of the building on both sides (see FIGURE 7). Less clearly, this pattern of post-holes is also visible on smaller buildings (e.g. Houses $27,38,3$, etc.). These posts must have stood upright, holding timber roof beams that ran along the longer sides of the trapezoidal floor. This 


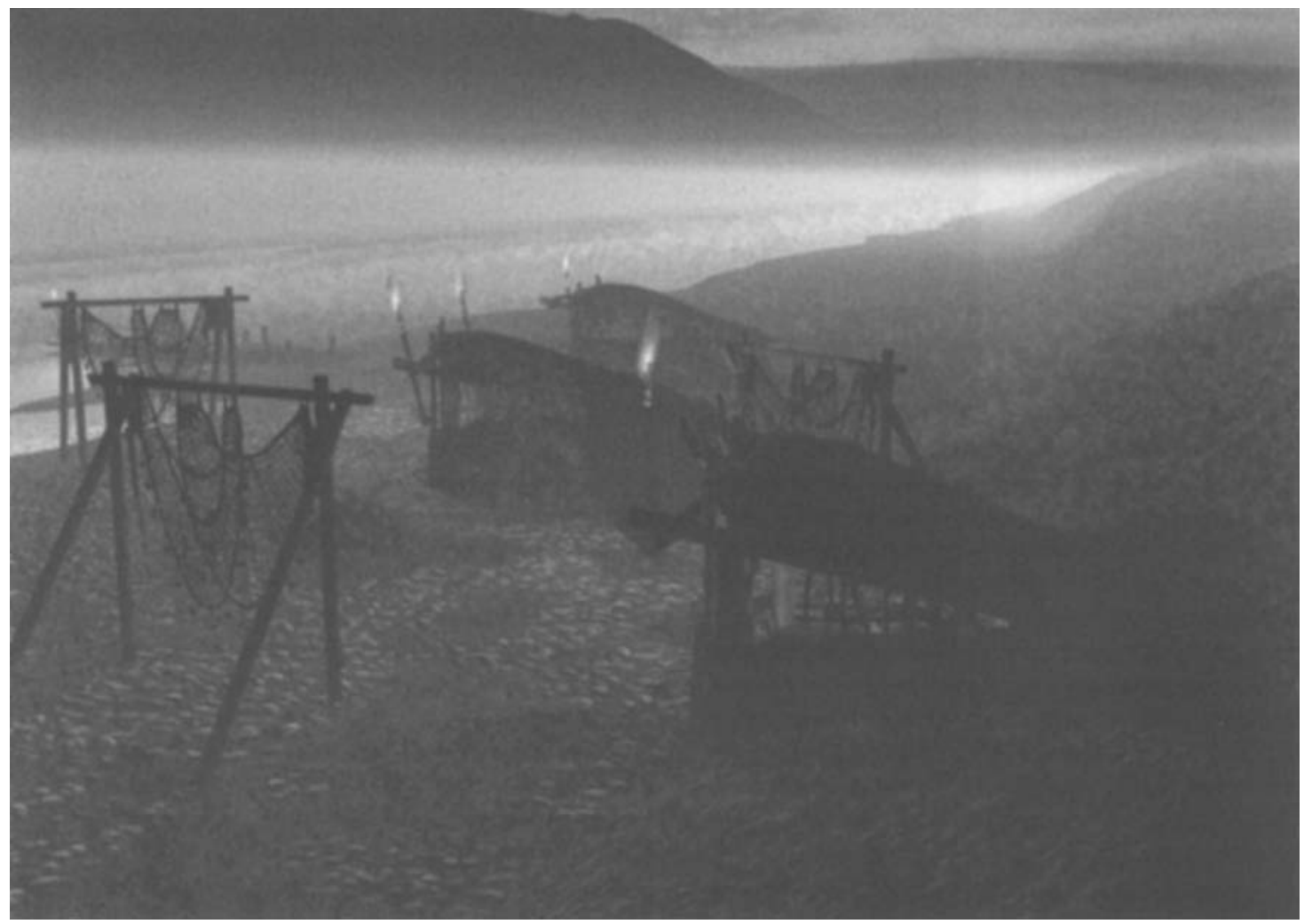

FiguRE 11. A settlement reconstruction of Lepenski Vir. (John Gordon Swogger, Bryce v. 5.0.)

is confirmed by the position of charred remains of timber beams found during the excavation that had collapsed along the longer sides of the buildings (Srejović 1966: 95; 1967a: 74). Similar constructional elements have also been identified at Padina (B. Jovanović pers. comm.). One can only speculate that the roof was constructed from materials such as wood, reed, hides, etc. This might have been a relatively light construction (FIGURE 11). Further analyses are necessary to elucidate the upper construction of rectangular hearths in the centre of these structures, which all have a distinct black (burnt) elliptical stripe ( $c f$. Srejović 1969; 1972; Radovanović 1996a). Thus, it is apparent that most of the features of Lepenski Vir II and IIIa-b are part of Lepenski Vir I dwellings.

\section{The frontier model and the 'Iron Gates Mesolithic'}

The availability model of a moving frontier for the transition to farming has become popular in European prehistory (e.g. Zvelebil 1986; Gregg
1988; Zvelebil \& Lillie 2000). This model identifies farmers and foragers as pre-formed entities and presents cultural change as an outcome of their interaction. Postcolonial sympathy for the foragers is implicit in this model type. Its narrative structure can be described as romantic (sensu White): "nostalgia for a "golden past" of originally affluent hunter-gatherers and identification with "Mesoliths"' (Pluciennik 1999: 664). The most problematic aspect of these models, however, is their essentialist theoretical stand. They generate and use categories of foragers and farmers by simplifying and dichotomizing the construction of past identities during the historic period of the MesolithicNeolithic transition. Additionally, proponents of this model maintain that 'the shift in the mode of subsistence to agro-pastoral farming' is 'the key feature of the Neolithic' (Zvelebil \& Lillie 2000: 59).

Various versions of frontier models have come to dominate current debate in the Danube Gorges and the north-central Balkans (e.g. Chapman 
1992; 2000; Budja 1999; Radovanović 1996a; Radovanović \& Voytek 1997; Voytek \& Tringham 1989; Tringham 2000; Zvelebil 1994: 119-20, etc.). For these authors, the Early Neolithic pottery (together with the Balkan flint and polished stone axes) in trapezoidal buildings of Lepenski Vir I is interpreted as a product of exchange, possibly prestigious, coming from contact with Early Neolithic communities surrounding the Gorges and the Mesolithic communities in the Gorges (Radovanović 1996b: 43; Chapman 1992; 2000; Radovanović \& Voytek 1997; Voytek \& Tringham 1989). These models evoke issues of domination and resistance around a wholly general argument about assimilation of Mesolithic communities after several centuries of resistance in the Danube Gorges (e.g. Chapman 1992; 2000; Radovanović 1996b; 2000b). Moreover, the economy of the communities is considered critical for the identification of society type irrespective of the historical context (Radovanović 1996a: 310; 2000b; Garašanin \& Radovanović 2001). Thus even after the identification of Early Neolithic pottery in association with the trapezoidal buildings of Lepenski Vir I, the paradigm of the 'Iron Gates Mesolithic' is retained and left unproblematic. Other similar models use some problematic aspects of chronology, stratigraphy and other data to develop further theories (e.g. Tringham 2000: 35, 47, footnote 5, etc.). There is also a tendency to consider 'farming' and 'agriculture' as self-explanatory concepts (e.g. Bonsall et al. 1997; 2000: 125, 127; Tringham 2000), as synonyms for the Early Neolithic in spite of the lack of evidence in pollen diagrams for any significant agricultural clearance in the Balkans before c. $5300 \mathrm{cal} \mathrm{BC}$ (Willis \& Bennett 1994).

My interpretation of the evidence from the Danube Gorges indicates long continuity in the use of the same locations and their recognition for several millennia, i.e. as early as $9800 \mathrm{cal}$ BC in the Upper Gorge (AMS date for Burial 72 at Vlasac, see Bonsall et al. 1997; 2000). The same subsistence practice of fishing and hunting continues from the Mesolithic to the Neolithic. Some change in the intake of migratory fish is possibly reflected in the isotopic data at the start of the Neolithic, yet faunal remains suggest both intensive fishing and hunting. No evidence is apparent indicating presence of domestic animals in deposits of these settlements, as has been suggested in scenarios of contact. Furthermore, there may have existed a complex seasonal schedule of subsistence activities (namely fishing) in the Gorges, possibly conflicting with previous models envisioning complex and sedentary fisherhunter-gatherers. Distinct architectural features of rectangular hearths are elaborated into domestic areas with trapezoidal floors and are frequently transformed into tombs, depending on the specific life cycles of these structures and their inhabitants (Borić in press). The architectural form of trapezoidal buildings is characteristic of the Upper Gorge (Vlasac, Lepenski Vir and Padina) and its elaboration starts in the Mesolithic context of Vlasac. However, at Padina and Lepenski Vir, Early Neolithic pottery, yellow-spotted Balkan flint and polished stone axes of the Starčevo-Körös-Crîş culture complex of the north-central Balkans are associated with most of the trapezoidal buildings. This abundant Early Neolithic material culture was probably accepted swiftly and might have been locally manufactured. The radiometric dates indicate that these settlements remained stable throughout the duration of the Early Neolithic. Physical anthropology confirms the existence of individuals of heterogeneous origins and we should expect infiltration of individuals from the wider region. Human skeletons exhibit both extremely robust and gracile features throughout the sequence, but this might be a consequence of long histories of occupation of these locales and local micro-evolution, foreign immigrants of different origin, sexual dimorphism and/or occupational activities. On the basis of skeletal material, there is no evidence to support the idea that some groups with clearly 'Neolithic' characteristics intensively mixed with the local population in this region at the start of the Early Neolithic (Roksandic 2000; contra Menk \& Nemeskéri 1989). All this points to the fact that the attribution of Mesolithic or Neolithic labels in the Danube Gorges on the basis of one single criterion is problematic.

Following Whittle (1998: 143-4), my reading of Lepenski Vir and other sites in the Danube Gorges and southeast Europe emphasizes the fluidity and non-fixation in the construction of collective and personal identities. Instead, one can emphasize the vision of identity constructed 'along multiple lines' (Meskell 2001: 199) and within a historical paradigm for what 
we conventionally call the Meso-Neo transition ( $c f$. Pluciennik 1998). In the Danube Gorges, complex practices of drawing deep into the past remained of substantial importance throughout the sequence as the expression of a specific (collective) cultural identity, belonging and common destiny. One can argue for a developed sense of 'deep time' in the transmission of collective memory - for instance, objectified through architectural iconography (Borić in press). However, similar sets of practices were taking varied forms in the wider Early Neolithic world of the north-central Balkans ( $c f$. Whittle 1998; Borić 1999). Indications for this are specific burial rights possibly echoing those in the Gorges, and two new AMS dates on human burials from Early Neolithic settlements in the Panonnian plain are clearly of the Mesolithic age (Whittle et al. 2001). One can best use the term 'mosaic' of processes (Tringham 2000; Whittle et al. 2001), suggesting a variability that surpasses any of the archaeological or ethnographic models currently available (cf. Pluciennik 1998).

The complexity of Lepenski Vir is responsible for the existing conundrum in its study to date. However it is our reluctance to appreciate fully this complexity and ambiguity of available evidence that prevents us from providing a thick description of the past, one that would replace uniform visions of culture change.

\section{Conclusion}

In this paper, I have reviewed a number of controversial aspects that particularly relate to Lepenski Vir, critical to the wider European debate on the Mesolithic-Neolithic transition. Any further models of the partly de-

\section{References}

ATLAS 1972. The Iron Gates Complex Atlas. Bucuresti.

Bonsall, C., R. LenNon, K. MCsweeney, C. Stewart, D. HARKNESS, V. BORONEANT, L. BARTOSIEWICZ, R. PAYTON \& J. ChAPMAN, 1997. Mesolithic and early Neolithic in the Iron Gates: a palaeodietary perspective, Journal of European Archaeology 5(1): 50-92.

BONSAll, C., G. COOK, R. LenNon, D. HaRkNess, M. SCOTt, L. BARTOSIEWICZ \& K. MCSWEENEY. 2000. Stable isotopes, radiocarbon and the Mesolithic-Neolithic transition in the Iron Gates, Documenta Praehistorica 27: 119-32.

BoNSALL, C. et al. In press. The Iron Gates prehistory: new perspectives. Oxford: BAR.

Borić, D. 1999. Places that created time in the Danube Gorges and beyond, c. 9000-5500 BC, Documenta Praehistorica 26: $41-70$.

In press. 'Deeptime' metaphor: mnemonic and apotropaic practices at Lepenski Vir, Journal of Social Archaeology 5(3). contextualized nature of the excavations at Lepenski Vir must include an awareness of the relationship of Early Neolithic pottery to the trapezoidal structures. The dating of the excavated features at this site is given precision through prior and new radiometric evidence. Recent synthesis of the evidence by Radovanović (1996a) falls short in these respects, as recently recognized (Borić 1999; Radovanović 2000a; Garašanin \& Radovanović 2001). I suggest a radical reworking of the stratigraphy and phasing of architectural features at Lepenski Vir. Some of the details in this interpretation are still preliminary, awaiting further AMS dates and detailed publication that will allow the construction of a high-resolution chronological scale. While awaiting this new body of data, we can re-think the validity of existing models that explain the culture change involved in the Mesolithic-Neolithic transition in the Danube Gorges. I argue that the dominant frontier models appear over-simplistic with an inherent essentialist perspective, which suffocates actual variability while the historic process of the Mesolithic-Neolithic transition is dichotomized between a monolithic view of foragers and farmers. A more nuanced approach is suggested with the emphasis on the historical context of the sequence and a multi-faceted perspective drawing on different lines of evidence.

Acknowledgements. I would like to thank Churchill College in Cambridge, the Studenica Foundation in San Rafael and the Open Society Institute in New York for funding my postgraduate research. I also thank Vesna Dimitrijević, Bryan Hanks, Ian Hodder, Andrew Jones, Preston Miracle, Sofija Stefanović and Alasdair Whittle for valuable comments on earlier versions of this paper, John Swogger for his help with building reconstructions and Borislav Jovanović for all his support and advice.

BudjA, M. 1999. The transition to farming in Mediterranean Europe - an indigenous response, Documenta Praehistorica 26: 119-41.

ChaPMAN, J.C. 1992. Social power in the Iron Gates Mesolithic, in J. Chapman \& P. Dolukhanov (ed.), Cultural transformations and interactions in Eastern Europe: 71-121. Aldershot: Avebury.

2000. Fragmentation in archaeology. People, places and broken objects in the prehistory of southeastern Europe. London: Routledge.

CoOK, G., C. Bonsall, R.E.M. Hedges, K. MCSWEeney, V BORONEANT, L. BARTOSIEWICZ \& P.B. PETTITT. 2002. Problems of dating human bones from the Iron Gates, Antiquity 76: 77--85.

DiMITRIJEVIĆ, V. In press. Lepenski Vir animal bones: what was left in the houses?, in Bonsall et al. (in press).

DIMTRJJEVĆ, V. \& D. BORIĆ Forthcoming. Animal bones from Padina. 
GaraŠanin, M. \& I. Radovanović. 2001. A pot in house 54 at Lepenski Vir I, Antiquity 75: 118-25.

GimBuTAS, M. 1976. Chronology, in M. Gimbutas (ed.), Neolithic Macedonia: as reflected by excavation at Anza, south. east Yugosiavia: 29-77. Los Angeles (CA): Institute of Archaeology, University of California at Los Angeles.

GREGG, S. 1988. Foragers and farmers. Chicago (IL): University of Chicago Press.

JOVANOVYĆ, B. 1969. Chronological frames of the Iron Gate Group of the Early Neolithic Period, Archaeologica Iugoslavica 10: $23-38$

1987. Die Architektur und Keramik der Siedlung Padina $B$ am Eisernen Tor, Jugoslawien, Germania 65(1): 1-16.

MARKOVIĆ-MARJANOVIĆ, $f$. 1978. Geologija i stratigrafija, in M. Garašanin (ed.), Vlasac-mezolitsko naselje u Djerdapu II: 11-27. Beograd: Srpska akademija nauka i umetnosti.

MESKELL, L. 2001. Archaeologies of identity, in I. Hodder (ed.), Archaeological theory today: 185-213. Cambridge: Polity Press.

MENK, R \& J. NEMESKÉRI. 1989. The transition from Mesolithic to Early Neolithic in southeastern and eastern Europe: an anthropological outline, in I. Hershkovitz (ed.), People and culture in change: Proceedings of the Second Symposium on Upper Palaeolithic, Mesolithic and Neolithic populations of Europe and the Mediterranean Basin: 531-40. Oxford: British Archaeological Reports. International series S508.

MilisaUSKAS, S. 1978. European prehistory. New York (NY): Academic Press.

PLUCIENNIK, M. 1998. Deconstructing 'the Neolithic' in the Mesolithic-Neolithic Transition, in M. Edmonds \& C Richards (ed.), Understanding the Neolithic of northwestern Europe: 61-83. Glasgow: Cruithne Press.

1999. Archaeological narratives and other ways of telling, Current Anthropology 40(5): 653-78.

PRICE, D. (ed.) 2000. Europe's first farmers. Cambridge: Cambridge University Press.

QUITTA, H. 1975. Die Radiocarbondaten und ihre historische Interpretation, in D. Srejović, Lepenski Vir. Eine vorgeschichtliche Geburtsstätte europäischer Kultur: 272 85. Bergisch Gladbach: Gustav Lübbe Verlag.

Radovanović, I. 1996a. The Iron Gates Mesolithic. Ann Arbor (MI): International Monographs in Prehistory. Archaeological Series 11.

1996b. Mesolithic/Neolithic contacts: a case of the Iron Gates region, Poročilo a raziskovanju paleolitika, neolitika in eneolitika v Sloveniji 23: 39-48.

2000a. The Lepenski Vir culture and its cultural identity, paper presented at the conference The Iron Gates Prehistory: new perspectives, 31 March-2 April 2000, Edinburgh.

2000b. Houses and burials at Lepenski Vir, European Journal of Archaeology 3(3): 330 -49

RADOVANOVIĆ, I. \& B. VOYTEK. 1997. Hunters, fishers or farmers: sedentism, subsistence and social complexity in the Djerdap Mesolithic, Analecta Praehistorica Leidensia 29: $19-31$.
RoKSANDIĆ, M. 2000. Between foragers and farmers in the Iron Gates Gorge: physical anthropology perspective. Djerdap population in transition from Mesolithic to Neolithic Documenta Praehistorica 27: 1-100.

SREJOVIĆ, D. 1966. Lepenski Vir, Boljetin. Neolitsko naselje, Arheološki pregled 8: 94-6.

1967a. Lepenski Vir, Boljetin - praistorijsko naselje, Arheološki pregled 9: 73-4.

1967b. Lepenski Vir. Iskopavanja 1965-1967. godine, Starinar 18: $157-66$

1968. Lepenski Vir (Boljetin) - predneolitska i neolitska naselja i nekropole, Arheološki pregJed 10: 85-7.

1969. Lepenski Vir - Nova praistorijska kultura u Podunavlju. Beograd: Srpska književna zadruga.

1971. Die Lepenski Vir-Kultur und der Beginn der Jungsteinzeit and der mittleren Donau, in $\mathrm{H}$. Schwabedissen (ed.), Die Anfänge des Neolithikums vom Orient bis Nordeuropa, Teil 2: Östliches Mitteleuropa: 1-19. Cologne: Fundamenta. Monographien zur Urgeschichte, Reihe A, Band 3.

1972. Europe's first monumental sculpture: new discoveries at Lepenski Vir. London: Thames \& Hudson.

1981. Lepenski Vir:Menschenbilder einer frühen europäischen Kultur. Mainz am Rhein: Verlag Philipp von Zabern.

SREJOVIĆ, D. \& LJ. BABOVIĆ. 1983. Lepenski Vir. Guide. Beograd: Narodni muzej.

SREjović, D. \& Z. Letica. 1978. Vlasac. Mezolitsko naselje u Djerdapu (I arheologija). Beograd: Srpska akademija nauka i umetnosti.

STEFANOVIC, S. \& D. BoRIĆ. In press. The new born infant burials from Lepenski Vir: in pursuit of contextual meanings, in Bonsall et al. (in press).

TRINGHAM, R, 2000. Southeastern Europe in the transition to agriculture in Europe: bridge, buffer or mosaic, in Price (ed.): $19-56$.

VOYTEK, B. \& R. TRINGHAM. 1989. Rethinking the Mesolithic: the case of southeast Europe, in C. Bonsall (ed.), The Mesolithic in Europe: 492-9. Edinburgh: John Donald Publishers Ltd.

WhitTLE, A. 1998. Fish, faces and fingers: presences and symbolic identities in the Mesolithic-Neolithic transition in the Carpathian Basin, Documenta praehistorica 25: 133-50.

Whittle, A., D. BoRić, L. BARTOSIEWiCz, P. PetTITT \& M. RICHARDS. 2001. In the beginning: new radiocarbon dates for the Early Neolithic in northern Serbia and southeast Hungary, Antaeus 25: 1-51.

WiLlIS, K.J. \& K.D. BENNETT, 1994. The Neolithic transitionfact or fiction? Palaeoecological evidence from the Balkans, The Holocene 4: 326-30.

ZVELEBIL, M. 1986. Mesolithic prelude and Neolithic revolution, in M. Zvelebil (ed.), Hunters in transition: 167-87. Cambridge: Cambridge University Press.

1994 (1995). Neolithization in Eastern Europe: a view from the frontier, Poročilio o raziskovanju paleolitika, neolitika in eneolitika v Sloveniji 22: 107-51.

ZVELEBIL, M. \& M. LILLLE, 2000. Transition to agriculture in eastern Europe, in Price (ed.): 57-92. 